\title{
PEMBINAAN SEMI MILITER SEBAGAI UPAYA MENGATASI DEGRADASI MORAL TERHADAP ANAK DIDIK PEMASYAKATAAN
}

\author{
Syahira', Irma Cahyaningtyas ${ }^{2}$ \\ Program Studi Magister Ilmu Hukum \\ Fakultas Hukum, Universitas Diponegoro \\ J alan Imam Bardjo, S.H. No. 1-3, Kampus Pleburan, Semarang 50241 \\ lerramasyhur@yahoo.com
}

\begin{abstract}
The increasing number of offenders is a serious problem. The impact of juvenile criminal behavior often requires that the child concerned be placed in a special child development institution (LPKA) and is a criminal child or correctional student. Criminal acts committed by children are caused by moral degradation in children. This writing outlines more about the causes of the moral degradation of children which can trigger children to commit acts that are classified as criminal acts. This writing also describes the author's ideas about semimiliter formation of correctional students. This writing uses a normative juridical research method as a basis for describing ideas. With the existence of semimiliter guidance on correctional students which are more oriented to changes in behavior and character of children to be more moral, it is expected to create the achievement of the goal of child development.
\end{abstract}

Keywords: J uvenile ; J uvenile Treatment ; Morality ; Quasi Militer.

\section{ABSTRAK}

Peningkatan jumlah anak pelaku tindak pidana menjadi masalah yang cukup serius. Dampak dari perilaku criminal anak seringkali mengharuskan anak yang bersangkutan ditempatkan dalam lembaga pembinaan khusus anak (LPKA) dan berstatus sebagai anak pidana atau anak didik pemasyarakatan. Tindak pidana yang dilakukan anak disebabkan oleh adanya degradasi moral dalam diri anak. Penulisan ini menguraikan lebih dalam mengenai penyebab terjadinya degradasi moral anak yang dapat memicu anak melakukan suatu perbuatan tindak pidana. Penulisan ini juga memaparkan gagasan penulis mengenai pembinaan semimiliter terhadap anak didik pemasyarakatan. Metode dalam penulisan ini menggunakan metode penelitian yuridis normative sebagai landasan dalam pendeskripsian gagasan. Dengan adanya pembinaan semimiliter terhadap anak didik pemasyarakatan yang lebih berorientasi pada perubahan perilaku dan karakter anak untuk lebih bermoral diharapkan dapat menciptakan tercapainya tujuan pembinaan anak.

Kata Kunci : Anak Pidana ; Pembinaan ; Moral ; Semimiliter.

\footnotetext{
${ }^{1}$ Mahasiswa Program Studi Magister IImu Hukum Universitas Diponegoro

${ }^{2}$ Dosen Program Studi Magister IImu Hukum Universitas Diponegoro
} 


\section{A. PENDAHULUAN}

Pada Konsideransi Undang - Undang Nomor 11 tahun 2012 tentang Sistem Peradilan Pidana Anak yang merupakan pengganti atas Undang Undang Nomor 3 tahun 1997 menyatakan bahwa :

"Anak adalah tunas, potensi, dan generasi muda penerus cita-cita perjuangan bangsa, yang memiliki peran strategis dan mempunyai ciri dan sifat khusus yang menjamin kelangsungan eksistensi bangsa dan negara pada masa depan".

Sehingga untuk mewujudkan perlindungan dan kesejahteraan anak diperlukan dukungan kelembagaan dan peraturan perundang-undangan yang dapat menjamin pelaksanaannya beserta peranan aparat penegak hokum dalam mencapai tujuan perlindungan anak yang sebaik-baiknya.

Jumlah kasus anak berhadapan dengan hukum mengalami peningkatan setiap tahunnya (diambil dari data KPAl melalui http://bankdata.kpai.go.id/ ). Meningkatnya jumlah tindak pidana dengan anak sebagai pelaku utamanya menjadi masalah yang sangat serius. Perbuatan pidana yang dilakukan oleh anak seringkali tidak hanya bersifat perseorangan melainkan juga dilakukan secara bersama-sama dengan orang dewasa maupun anak lain yang membuat keseluruhan dari anak-anak tersebut akhirnya berhadapan dengan hukum. Angka tertinggi tindak kejahatan yang dilakukan anak ada pada usia 15-19 tahun (Kartono, 2017). Anak dalam usia tersebut sedang memasuki fase pubertas dan adolescent dalam dirinya, dimana terdapat masa penghubung dan masa peralihan dari anak menjadi orang dewasa. Fase ini adalah fase terdapatnya pergolakan batin yang tinggi dalam diri anak remaja. Akan tetapi fase ini juga merupakan fase yang sangat cukup bagi mental dan psikologis anak untuk dapat menilai mana yang baik dan buruk untuk dilakukan artinya mereka telah sadar betul bahwa perbuatannya ialah perbuatan yang jahat akan tetapi dalam masa ini juga merupakan masa timbulnya gejolak batin dalam diri anak yang mendorong anak untuk 'mencoba' sesuatu baru.

Meningkatnya jumlah anak sebagai pelaku tindak pidana dipelopori oleh kurangnya pendidikan moralitas pada lingkungan sekitar seperti keluarga,kerabat dan sekolah yang berperan dalam kehidupan pribadi anak. Selain itu terdapat pula factor eksternal seperti perkembangan teknologi dan pengetahuan yang cukup pesat dalam era milenial saat ini. Dampak yang paling menonjol dalam diri anak ialah terkikisnya moral anak atau degradasi moral anak utamanya terjadi dalam era milineal saat ini. Degradasi moral ini merupakan hasil dari terjadinya globalisasi yang tanpa disadari telah merusak gaya hidup dan moral anak bangsa sehingga anak dapat dengan mudah melakukan sesuatu yang merusak dirinya sendiri dan menciderai nurani masyarakat. Degradasi moral sering juga disertai dengan pengertian yang rendah dan pemahaman yang minim mengenai nilai social dan norma etis di masyarakat (Kartono, 2017). Seorang anak yang telah terlanjur melakukan tindak pidana 
Jurnal Pembangunan Hukum Indonesia

Volume 1, Nomor 1, Tahun 2019
Program Studi Magister Ilmu Hukum Fakultas Hukum Universitas Diponegoro pada akhirnya berpotensi untuk dikenakan sanksi berupa pidana maupun tindakan yang berdasar pada bobot perbuatan yang telah dilakukannya.

Dalam hal anak yang dijatuhi sanksi berupa pidana penjara atau pembinaan , maka anak akan di tempatkan di Lembaga Pembinaan Khusus Anak (LPKA) dan disebut sebagai Anak Didik Pemasyarakatan (ANDIKPAS) .

Definisi Anak Didik Pemasyarakatan berdasarkan Pasal 1 Undang-Undang Nomor 12 tahun 1995 tentang Lembaga Pemasyarakatan adalah:

a. Anak Pidana yaitu anak yang berdasarkan putusan pengadilan menjalani pidana di LAPAS Anak paling lama sampai berumur 18 (delapan belas) tahun (dalam UU No 11 tahun 2012 tentang Sistem Peradilan Pidana Anak, anak pidana sama dengan anak binaan.);

b. Anak Negara yaitu anak yang berdasarkan putusan pengadilan diserahkan pada negara untuk dididik dan ditempatkan di LAPAS Anak paling lama sampai berumur 18 (delapan belas) tahun;

c. Anak Sipil yaitu anak yang atas permintaan orang tua atau walinya memperoleh penetapan pengadilan untuk dididik di LAPAS Anak paling lama sampai berumur 18 (delapan belas) tahun.

LPKA Dalam Perspektif Sistem Peradilan Pidana Anak difokuskan pada tiga hal utama, yaitu pembinaan fisik, mental dan social (Penjelasan Pasal 32 ayat (1) Undang - Undang Nomor 11 Tahun 2012 Tentang Sistem Peradilan Pidana Anak). Diperlukan suatu upaya khusus dalam meningkatan kembali moralitas anak bangsa yang telah surut dalam diri anak didik pemasyarakatan (ANDIKPAS); dalam hal ini pembinaan yang dilakukan dalam LPKA memerlukan suatu gagasan baru untuk mengatasi masalah tersebut sehingga dalam hal ini penulis memberikan ide berupa pendidikan semi militer terhadap anak binaan yang akan memberikan suatu pendidikan karakter sekaligus pendidikan moral terhadap anak.

Menurut Muladi (Muladi \& Arief, 2010) tujuan pemidanaan adalah untuk memperbaiki kerusakan individual dan sosial (individual and social damages) yang diakibatkan oleh tindak pidana. Terdapat beberapa tujuan pemidanaan yang ingin dicapai yaitu pencegahan umum maupun khusus, perlindungan masyarakat, memelihara solidaritas masyarakat dan pengimbalan atau pengimbangan. Re-Integrasi sosial berasumsi bahwa pelanggaran hukum terjadi bukan hanya karena kesalahan individu tetapi juga masyarakat mempunyai andil terhadap terjadinya pelanggaran hukum tersebut. Sehingga diperlukan suatu metode khusus terhadap pelaku pelanggaran hukum semasa menjalani masa pertanggungjawaban pidananya agar tidak kembali melakukan pelanggaran.

Sanksi / hukuman terhadap Anak yang Berkonflik dengan Hukum merupakan salah satu sarana yang ingin direncanakan untuk mencapai tujuan tersebut (Arief, 2007). Sebagai dasar pembenar atau tolak ukur yang dipakai dalam pembahasan terhadap permasalahan dari sanksi/ hukuman anak yang Berkonflik dengan Hukum adalah ditekankan pada aspek-aspek pokok tersebut yaitu perlindungan secara integratif antara perlindungan masyarakat dan perlindungan individu khususnya anak-anak yang berkonflik dengan 
Jurnal Pembangunan Hukum Indonesia

Volume 1, Nomor 1, Tahun 2019
Program Studi Magister Ilmu Hukum Fakultas Hukum Universitas Diponegoro
Hukum agar terhindar dari dampak negatif dari pidana penjara karena masih memiliki jiwa yang labil dan demi masa depan anak yang masih panjang (Hadisuprapto, 2008).

Sistem Peradilan Pidana Anak telah memasuki babak barunya melalui munculnya ide double track system. Ide dasar double track system dalam menjatuhkan sanksi terhadap anak yang melakukan kejahatan dinilai sangat tepat untuk diterapkan karena disamping untuk mengindari dampak negatif pidana hilang kemerdekaan maka anak dimungkinkan untuk memperoleh pembinaan guna perkembangan masa depannya. Perlakuan terhadap anak perlu dibedakan karena pada saat itu darah, tubuh dan jiwa si anak sedang mengalami perkembangan. Dapat dikatakan bahwa si anak sedang dalam keadaan labil. Jadi ada sesuatu yang berbeda ketika kita berbicara tentang anak. (Soetodjo \& Melani, 2013)

Perlu diketahui bahwa, munculnya pemikiran double track system menghendaki agar unsur pencelaan / penderitaan dan unsur pembinaan samasama diakomodasi dalam sistem sanksi hukum pidana. Inilah yang menjadi dasar penjelasan mengapa dalam double track system dituntut adanya kesetaraan antara sanksi pidana dan tindakan (M. Sholehuddin ,2004).

Anak bukan orang dewasa dalam ukuran mini, karena itu dia tidak bisa disamakan dengan miniatur dari orang dewasa, karena itu kita harus memberikan treatment yang berbeda. Kemudian anak juga sedang dalam masa pertumbuhan dan situasi ini masuk kelompok rawan yang harus diproteksi sejak awal. Hal itu yang menyebabkan perlu adanya pembedaan perlakuan terhadap anak dalam penegakan hukum (Kartono, 2017)

Salah satu efek negatif dari pelaksanaan pidana penjara adalah terjadinya stigmatisasi atau pemberian "cap jahat" terhadap mantan narapidana. Masyarakat seringkali tidak percaya terhadap mantan narapidana, bahkan secara kultural kehadiran narapidana ditolak oleh masyarakat. Stigma dan penolakan tersebut menyebabkan tekanan psikologis pada mantan narapidana, bahkan keluarga juga ikut merasakan rasa malu. Perspektif teori labelling, tekanan psikologis dan stigma dari masyarakat (sebagai deviasi primer) kadangkala akan mendorong mantan narapidana melakukan kejahatan (sebagai deviasi sekunder) (Widodo, 2014). Seperti diketahui bahwa teori labelling yang dikemukakan oleh Lamert (Santosa, 2014) adalah teori yang menganut prinsip bahwa stigma negatif dan pandangan masyarakat dengan pemberian "cap jahat" terhadap seorang pelanggar norma atau pelaku kejahatan secara berangsur-angsur memiliki pengaruh besar dalam perkembangan jiwa orang tersebut (Santosa, 2014). Orang tersebut pada akhirnya dapat benar-benar melakukan suatu kejahatan. Oleh karena itu, dibutuhkan suatu pembinaan khusus di dalam LP yang nantinya dapat mengubah paradigma masyarakat terhadap mantan anak binaan atau ex-narapidana anak. Walau bagaimanapun untuk mengubah budaya yang ada di masyarakat akan mengalami banyak kendala, akan 
tetapi melalui gagasan ini diharapkan mampu meminimalisir stigma di masyarakat terhadap mantan narapidana anak. Berdasar pada latar belakang diatas maka dalam jurnal ini akan dibahas lebih lanjut mengenai mengapa degradasi moral terjadi pada anak didik pemasyarakatan dan bagaimana ide pembinaan semi militer terhadap anak didik pemasyarakatan atau anak binaan dalam LPKA yang digagas oleh penulis. Tujuan yang akan dicapai dari adanya penulisan jurnal ini ialah antara lain ialah untuk mengetahui faktor terjadinya degradasi moral pada anak dan untuk memaparkan mengenai ide pembinaan semi militer terhadap anak binaan atau anak didik pemasyarakatan di dalam LPKA.

Metode Pendekatan yang digunakan dalam penelitian ini adalah pendekatan Yuridis Normatif (Soekanto dan Mamudji,2013) yaitu sebuah penelitian yang dilakukan dengan meneliti bahan pustaka atau bahan sekunder. Penelitian hukum adalah sebuah proses untuk menemukan aturan hukum, prinsip-prinsip hukum maupun doktrin hukum yang berguna untuk menjawab isu yang sedang dihadapi (Marzuqi, 2005). Metode Yuridis normatif menekankan kepada pendekatan norma-norma atau aturan yuridis seperti Undang - Undang dan peraturan lainnya yang berkaitan dengan masalah yang sedang diteliti. Dalam hal ini pendekatan dimulai dengan mengadakan pengumpulan atau inventarisasi literatur yang berkaitan dengan system pemidanaan anak.

\section{B. HASIL DAN PEMBAHASAN}

\section{Degradasi Moral Anak Didik Pemasyarakatan}

Kejahatan yang dilakukan oleh anak-anak muda usia produktif pada intinya merupakan produk dari kondisi masyarakatnya dengan segala pergolakan social yang ada di dalamnya. Kejahatan yang dilakukan anak remaja ini disebut sebagai penyakit masyarakat atau penyakit social. Penyakit sosial atau penyakit masyarakat adalah suatu bentuk tingkah laku yang dianggap tidak sesuai, melanggar norma-norma umum dan hokum formal yang berlaku di masyarakat.

Pengaruh social dan kultural memainkan peranan yang besar dalam pembentukan atau pengkondisian tingkah laku criminal anak-anak remaja. Perilaku anak-anak remaja ini menunjukkan tanda-tanda kurang mampu atau tidak adanya kesepakatan terhadap norma-norma social. Mayoritas juvenile delinquency berusia dibawah 21 tahun. Angka tertinggi kejahatan ada pada anak usia 15-19 tahun; dan sesudah 22 tahun kasus kejahatan yang dilakukan oleh gang-gang delinkuen akan menurun.

Anak-anak remaja yang melakukan kejahatan itu pada umumnya kurang memiliki control diri, atau justru menyalahgunakan control diri tersebut, dan suka menegakkan standar tingkah laku sendiri, di samping meremehkan keberadaan orang lain. Anakanak pelaku kejahatan pada umumnya sangat egoistic, dan suka menyalahgunakan atau melebihlebihkan harga dirinya (kartono ; 2017). Karenanya dalam masa remaja atau fase peralihan inilah peran 
keluarga, kerabat maupun lingkungan menjadi sangat penting sebagai sarana pendidikan moral atau pengendali nafsu anak dalam berbuat kenakalan. Kurangnya control orang dewasa terhadap anak menambah semakin kuatnya keinginan anak untuk menyalurkan nafsunya dan memikirkan dirinya sendiri.

Kurangnya control maupun perhatian dari orang dewasa dalam perkembangan pribadi anak pada awalnya akan memunculkan pemikiran dalam diri anak bahwa ia telah diasingkan atau disisihkan dari lingkungannya. Anak akan merasa tidak puas terhadap kondisi lingkungan dan kewibawaan orang dewasa yang acuh tersebut. Dalam kondisi yang demikian ini anak akan membatasi dirinya terhadap lingkungan kerabat dan mencoba untuk membuat dunia baru diluar lingkungan dekatnya dan mengembangkan paham individualism di dalam dirinya. Di tambah lagi dengan di dorong oleh kebutuhan untuk menonjolkan ego serta dorongan untuk menghilangkan kejemuan dan mengisi kekosongan hati akibat perasaan tersisih dari lingkungan kerabatnya.

Segala gejala keberandalan dan kejahatan yang muncul itu merupakan akibat dari proses perkembangan pribadi anak yang mengandung unsur dan usaha :

1. Kedewasaan seksual ;

2. Pencaharian suatu indentitas kedewasaan;

3. Adanya ambisi materiil yang tidak terendali ;

4. Kurang atau tidaknya disiplin diri (Kartono,2017)
Maka dalam konteks perspektif baru dari periode adolescent ke remaja, gang delinkuen tadi mengintepretasikan sebagai manisfestasi kebudayaan remaja dan tidak dilhat sebagai bagian dari gang-gang kriminal orang dewasa.

Kejahatan anak remaja merupakan produk sampingan dari (Kartono, 2017) :

a) Pendidikan massal yang tidak menekankan pendidikan watak dan kepribadian anak ;

b) Kurangnya usaha orangtua dan orang dewasa dalam menanamkan moralitas dan keyakinan beragama pada anak-anak ;

c) Kurang ditumbuhkannya tanggung jawab social pada anak-anak remaja

Semua bentuk perubahan dalam struktur social itu sangat mempengaruhi pola hidup kaum remaja. Karena dalam usia remaja merupakan periode transisi penuh badai dalam kehidupan batiniyah seorang remaja yang dapat berakibat pada melemahnya kejiwaan mereka sehingga mudah dipengaruhi oleh rangsangan-rangsangan eksternal. (kartono;2017)

Anak-anak remaja yang melakukan kejahatan itu pada umumnya kurang memiliki kontrol diri, atau justru meyalahgunakan kontrol diri tersebut dan suka menegakkan standar tingkah laku sendiri disamping meremehkan keberadaan orang lain. Kejahatan yang mereka lakukan itu pada umumnya disertai unsurunsur mental dan motif-motif subyektif, yaitu untuk mencapai suatu obyek tertentu dengan disertasi kekerasan dan agresi. Pada umumnya anak-anak muda tadi sangat egoistis dan suka sekali 
menyalahgunakan atau melebih-lebihkan harga dirinya. Adapun motif yang mendorong mereka melakukan kejahatan atau kedursilaan itu antara lain ialah :

1. Untuk memuaskan kecenderungan keserakahan;

2. Meningkatkan agresivitas dan dorongan seksual;

3. Salah asuh dan salah didik orang tua sehingga anak menjadi manja dan lemah mentalnya;

4. Hasrat untuk berkumpul dengan kawan senasib dan sebaya serta kecenderungan untuk meniruniru teman;

5. Kecenderungan pembawaan yang patologis atau abnormal ;

6. Konflik batin sendiri dan kemudian menggunakan mekanisme pelarian diri serta pembelaan diri yang irrasional

Dengan demikian, dapat disimpulkan bahwa Juvenile Delinquency adalah suatu tindakan atau perbuatan pelanggaran norma social yang dilakukan oleh anak-anak usia muda.

Adapun motif yang mendorong anak melakukan kejahatan antara lain :

1. Untuk memuaskan kecenderungan keserakahan

2. Meningkatnya agresivitas dan dorongan seksual

3. Salah asuh dan salah didik orangtua, sehingga anak menjadi manja dan lemah mentalnya

4. Hasrat untuk berkumpul dengan kawan-kawan senasib, sebaya, dan kesukaan mereka untuk meniru-niru

5. Kecenderungan pembawaan yang abnormal
6. Konflik batin sendiri, dan kemudian menggunakan mekanisme pelarian diri serta pembelaan diri diluar rasional.

Ciri yang paling mencolok dari terjadinya gejala penyakit social maupun kenakalan remaja tersebut di atas ditandakan dengan adanya degradasi moralitas pada anak.

Dalam Kamus Besar Bahasa Indonesia, Degradasi diartikan sebagai kemerosotan atau kemunduran dan moral menurut (Hurlock,1993) dalah tata cara kebiasaan dan adat dimana dalam perilaku dikendalikan oleh konsep-konsep moral yang memuat peraturan yang telah menjadi kebiasaan bagi anggota suatu budaya dan yang menentukan dalam perilaku yang diharapkan oleh seluruh anggota kelompok. Dengan demikian, dekadensi moral merupakan suatu keadaan dimana telah terjadi kemerosotan moral yang bermakna bahwa individu maupun kelompok telah tidak menaati aturan serta tata cara yang berlaku di masyarakat. Guna memperjelas mengenai definisi moral,Kohlberg (Mansur, 2006) mengungkapkan bahwa moral menyangkut kegiatan-kegiatan manusia yang dipandang sebagai baik/buruk, benar/salah, tepat/tidak tepat, atau menyangkut cara seseorang bertingkah laku dalam hubungan dengan orang lain. Kemunduran kesadaran masyarakat yang dirasakan saat ini perlu dibangkitkan agar perkembangan moral anak (remaja) dapat menjadi lebih baik, karena masyarakat juga berperan penting di dalamnya. Untuk mencegah hal tersebut serta memperbaikinya 
harus dipahami gejala penurunan moral yang terjadi pada anak (Jahroh\&Sutarna,2016)

Menurut (Lickona ,2013) ada 10 indikasi gejala penurunan moral yang perlu mendapatkan perhatian agar berubah ke arah yang lebih baik; 1) Kekerasan dan tindakan anarki, 2) Pencurian, 3) Tindakan Curang, 4) Pengabaian terhadap aturan yang berlaku, 5) Tawuran antar siswa, 6) Ketidaktoleran, 7) Penggunaan bahasa yang tidak baik, 8) Kematangan seksual yang terlalu dini dan penyimpangannya, 9) Sikap perusakan diri, 10) Penyalahgunaan Narkoba.

Degradasi moral merupakan hasil dari terjadinya globalisasi yang tanpa disadari telah merusak gaya hidup dan moral anak bangsa sehingga anak dapat dengan mudah melakukan sesuatu yang merusak dirinya sendiri dan menciderai nurani masyarakat, salah satunya yang tergolong dalam tindak pidana. Dalam pandangan hukum pidana anak yang telah terlanjur melakukan perbuatan melanggar norma yang termasuk dalam tindak pidana menurut Undang -Undang yang berlaku dapat dijatuhi hukuman pidana salah satunya pidana penjara. Dalam pelaksanaannya seorang anak yang dijatuhi pidana penjara ditempatkan di dalam Lembaga Pembinaan Khusus Anak (LPKA) yang di dalamnya terdapat berbagai jenis pembinaan terhadap anak yang diselenggarakan oleh Negara. Akan tetapi pembinaan tersebut seringkali tidak berlaku efektif akibat sarana dan prasarana yang kurang memadai maupun kapasitas anak yang tidak sesuai dengan jumlah Pembina. Anak binaan yang merupakan korban penurunan moralitas perlu mendapatkan pembinaan yang dapa meningkatkan kembali moral dan jiwa social dalam dirinya, sehingga diperlukan suatu pembinaan yang bersifat khusus dalam menangani hal tersebut

\section{Ide Pendidikan Semi Militer Terhadap Anak Didik Pemasyarakatan}

Pendidikan semi militer terhadap anak didik pemasyarakatan (selanjutnya akan disebut ANDIKPAS) khususnya anak yang sedang menjalani masa pidananya pada dasarnya ditujukan pada mental dan jiwa spiritual dalam diri anak. Anak sebagai pelaku tindak pidana disamping merupakan korban dari lingkungan sekitar tempat tinggalnya maupun faktor luar lainnya yang menyebabkan dirinya mendekati perbuatan yang dilarang, seorang anak pelaku tindak pidana dalam hal mekakukan perbuatannya disebabkan oleh kurangnya penanaman nilai-nilai luhur dan moralitas di dalam dirinya sehingga diperlukan adanya suatu pembinaan berupa pendidikan dengan sasaran aspek-aspek Mental Spiritual, Mental Ideologi, Mental Kejuangan dan Kepemimpinan agar ANDIKPAS tersebut dapat menjadi pribadi yang tangguh dan siap menghadapi hal apapun yag akan terjadi dalam dunianya. Di samping itu melalui pembinaan ini juga diharapkan tertaman jiwa nasionalis yang dipenuhi oleh nilai-nilai dasar dalam diri anak untuk nantinya dalam jangka waktu kedepan dapat menjadi faktor penghalang diri anak untuk melakukan perbuatan immoral atau perusak moral maupun sampai kembali mengulang Tindak Pidana. Gagasan mengenai pembinaan ini 
bersumber pada system pembinaan anak nakal yang dipakai oleh negara Amerika. Pembinaan semacam ini di Amerika bernama juvenile booth camp. J uvenile Booth Camp adalah suatu program pelatihan khusus yang berbasis militer maupun semi militer dengan memfokuskan pada perubahan perilaku anak nakal untuk menjadi lebih baik dari sebelumnya (Gültekin, Kübra , Gültekin Sebahattin, 2012) . J uvenile Booth Camp dianggap sebagai shock theraphy bagi anak remaja yang melanggar norma-norma di masyarakat. Dalam pelaksanaannya juvenile booth camp dianggap cukup efektif dalam menanggulangi anakanak nakal, tetapi kurang efektif dalam penanganan residivis anak (Gültekin, Kübra, Gültekin Sebahattin, 2012). Dengan mengadopsi ide tersebut maka penulis memiliki gagasan mengenai pembinaan semi militer terhadap ANDIKPAS. Tujuan dari pendidikan ini selain untuk membentuk karakter anak juga sebagai upaya pembelaan negara yang merupakan kewajiban bagi tiap individu Negara dalam rangka mencapai tujuan negara. Sebagaimana tujuan Negara Indonesia yakni melaksanakan ketertiban dunia termaktub dalam pembukaan alinea ke 4 (empat) Undang-Undang Dasar Negara Republik Indonesia Tahun 1945.

Hal tersebut sejalan dengan pemikiran Lickona (Lickona : 2013) bahwa dalam karakter yang baik harus terkandung tiga komponen yaitu pengetahuan moral, perasaan moral, dan tindakan moral melalui tiga komponen tersebut pendidikan karakter akan berjalan secara sistematis dan berkelanjutan sehingga anak didik pemasyarakatan nantinya dapat menilai suatu tindakan melalui pengetahuannya, dapat merasakan suatu tindakan melalui perasaan moralnya serta dapat memutuskan tindakan tersebut melalui tindakan moral yang dimiliki siswa. Tanpa ketiga komponen ini maka pembinaan semi militer yang bertujuan untuk pembentukan karakter baru terhadap anak didik pemasyarakatan tidak akan berjalan secara efektif.

Maraknya kasus kejahatan utamanya kejahatan yang melibatkan anak di Indonesia dimulai dari kejahatan ringan hingga jenis kejahatan berat mengakitbatkan anak usia produktif 14-18 tahun mendekam dibalik jeruji penjara tanpa menikmati kehidupan seperti hal nya anak-anak seusianya. Salah satu factor penyebab hal tersebut ialah pergeseran nilai - nilai budaya dimasyarakat sebagai dampak dari globalisasi. Pendidikan semi militer terhadap anak di dalam Lembaga Pemasyarakatan dengan lebih mengedepankan cinta tanah air dan jiwa korsa dalam diri anak ialah suatu gagasan yang dapat meningkatkan kualitas jiwa kemanusiaan dalam diri anak khususnya ANDIKPAS / Anak yang Berhadapan Dengan Hukum (ABH) . Tujuannya adalah untuk menciptakan generasi yang berkualitas dan terhindar dari degradasi moral sekaligus dapat menertibkan diri anak pidana untuk melakukan sesuatu sesuai dengan norma mauun kaidah-kaidah yang berlaku dalam kehidupan masyarakat.

Perwujudan dari ide ini tentunya tidak luput dari empat prinsip hak dasar anak dalam konvensi hak- hak anak 1989 (Convention on the Right of the Child Resolusi PBB 20 September 1989) yang terdiri 
dari : 1) Non diskriminasi ;

kepentingan terbaik bagi anak ; 3) hak untuk hidup, kelangsungan \& perkembangan anak ; serta ; 4) penghargaan terhadap pendapat anak.

Non-diskriminasi menurut Konvensi Hak Anak artinya tidak membeda-bedakan status anak pidana berdasarkan pada ras,suku,budaya maupun agama yang dianutnya. Implementasi prinsip dasar dalam ide ini adalah dengan memberlakukan system pembinaan dalam LPKA terhadap seluruh ANDIKPAS tanpa terkecuali. Sesuai dengan yang telah dijelaskan sebelumnya, bahwa tujuan dari pembinaan semimiliter terhadap anak dalam LPKA ini ialah untuk membangun mental anak dalam menghadapi kemungkinan-kemungkinan yang terburuk sekalipun nantinya dalam kehidupan setelah dipidana. Menjadikan anak untuk memiliki ketangguhan jiwa dan semangat dalam menjalani hidup serta memiliki tingkat moralitas yang tinggi agar dapat menjadi manusia yang bermanfaat bagi lingkungan sekitar. Hal ini senada dengan prinsip kepentingan terbaik bagi anak yang tercantum dalam konvensi hak-hak anak 1989. Dengan memiliki modal kepribadian yang bermoral dan mencerminkan nilainilai Pancasila nantinya diharapkan dapat menjamin ex-napi anak untuk lebih mudah diterima kembali dalam masyarakat. Sehingga ex-napi anak tidak lagi disebut sebagai mantan narapidana melainkan selayaknya anak yang pernah melakukan kesalahan dan telah mempertanggungjawabkan kesalahan tersebut di masa lalu. Dengan hilangnya julukan mantan narapidana secara bertahap dapat
2) meningkatkan kembali kepercayaan diri anak dalam menjalani fase-fase kehidupan selanjutnya, anak akan lebih mudah dalam membangun kembali hubungan dengan masyarkat sekitarnya. Keseluruhan dari proses tersebut telah memenuhi dua prinsip dasar lainnya yaitu hak untuk hidup, dan mendapat keberlangsungan hidup serta penghargaan terhadap pendapat anak yang dalam hal ini identik dengan penghargaan terhadap upaya anak dalam memperbaiki diri.

Dengan hasil yang demikian maka secara langsung ide pembinaan ini telah menerapkan keempat prinsip dasar hak-hak anak yang wajib dijunjung tinggi dan diselenggarakan oleh Negara.

Upaya mewujudkan gagasan ini menurut penulis ialah dengan melakukan Kerjasama antar LPKA dengan lembaga pendidikan dibawah naungan kementerian pertahanan dan keamanan Negara. Seperti yang kita ketahui bahwa di Indonesia terdapat beberapa lembaga pendidikan yang berada dibawah naungan kementrian Pertahanan dan Keamanan Negara yang bertujuan untuk menyiapkan jiwa anak didik yang berkualitas, berkarakter dan berbudaya serta menyiapkan individu yang memiliki kesetiaan terhadap Bangsa dan Negara Kesatuan Republik Indonesia yang berdasarkan Pancasila dan UUD 1945 . Berdasarkan informasi yang penulis dapatkan anak dalam lembaga pendidikan tersebut ketika memasuki tahap akhir dalam menuntut ilmu memiliki kewajiban untuk terjun langsung ke lapangan dan membantu masyarakat dalam hal yang berkaitan dengan pendidikan yang telah mereka 
kuasai dalam kurun waktu tertentu. Dengan adanya kesempatan ini menurut hemat penulis akan lebih baik apabila sasaran terjun mereka ialah anak-anak didik pemasyarakatan (ANDIKPAS) dalam LPKA setempat atau yang berada dalam wilayah terdekat. Apabila memungkinkan dapat pula dilakukan dengan menghadirkan ANDIKPAS ke sekolah atau asrama pendidikan dalam kurun waktu tersebut atas dasar pertimbangan sarana dan prasarana yang lebih memadai dalam lingkungan pendidikan yang bersangkutan. Tahap selanjutnya dalam pengimplementasian gagasan ini ialah dengan memisahkan jenis pendidikan berdasarkan pada latar belakang tindak pidana yang dilakukan oleh anak. Seperti misalnya terhadap anak pelaku Tidak Pidana Umum dengan anak usia 14-18 tahun, dapat dilakukan bentuk pembinaan berupa pelatihan kenusantaraan seperti penanaman jiwa nasionalisme; pengamalan dan penanaman nilai-nilai Pancasila ; Pengenalan akan budaya-budaya Indonesia khususnya budaya sopan-santun ; dan lain sebagainya. Sedangkan terhadap anak pelaku Tindak Pidana Khusus seperti narkoba,terorisme, dan lain sebagainya dapat dikenai pembinaan dalam bentuk bela negara, yang mencakup pelatihan ketahanan tubuh, pelatihan jiwa korsa dan penanaman jiwa tanah air.

\section{SIMPULAN}

Memasuki fase remaja yang dialami oleh anak , pada umumnya merupakan masa-masa terpenting dan tersulit bagi anak. Dalam masa ini anak pada umumnya mulai memiliki keinginan untuk unjuk kemampuan dirinya. Dalam tahap tersebut diperlukan adanya control dari orang dewasa di lingkungan anak agar anak tidak terjerumus ke dalam hal-hal yang negative. Perkembangan diri anak diluar control oang dewasa yang dibarengi dengan kemajuan ilmu pengetahuan dan teknologi dapat memberi pengaruh buruk terhadap anak. Degradasi moral merupakan hasil dari terjadinya globalisasi yang tanpa disadari telah merusak gaya hidup dan moral anak bangsa sehingga anak dapat dengan mudah melakukan sesuatu yang merusak dirinya sendiri dan menciderai nurani masyarakat, salah satunya yang tergolong dalam tindak pidana. Dalam hal anak melalukan tindak pidana dapat berakibat pada keharusan anak tersebut untuk mempertanggungjawabkan perbuatannya. Bentuk pertanggungjawaban anak pelaku tindak pidana salah satunya ialah dengan menjalani hukuman pidana berupa pidana penjara atau disebut sebagai Anak Dididk Pemasyarakatan. Dalam proses pemidanaannya seorang anak ditempatkan dalam Lembaga Pembinaan Khusus Anak (LPKA) dan wajib mengikuti seluruh proses pembinaan yang bertujuan untuk memulihkan keadaan ANDIKPAS dalam hal ini yakni pemulihan perilaku anak menjadi lebih baik. Gagasan Pemberian Pendidikan semi militer terhadap ANDIKPAS dalam proses pembinaan di dalam LPKA memiliki sasaran aspek-aspek Mental Spiritual, Mental Ideologi, Mental Kejuangan dan Kepemimpinan agar ANDIKPAS dapat menjadi pribadi yang tangguh dan siap menghadapi hal apapun yang akan terjadi dalam dunianya, serta 
tertaman jiwa nasionalis dalam dirinya yang mana dalam jangka waktu kedepan hal tersebut dapat menjadi faktor penghalang diri anak untuk kembali mengulang TP. Dengan dimplementasikannya gagasan ini maka pemidanaan anak dapat berlangsung efektif dan sekaligus dapat mencapai tujuan hukum pidana yakni menanggulangi kejahatan dan mengurangi residivis.

\section{DAFTAR PUSTAKA}

\section{BUKU}

Arief, Barda N. (2007). Bunga Rampai Kebijakan Hukum Pidana. Jakarta: Prenada Grup.

Arief, Barda N., \& Muladi. (2010) . Teori-Teori \& Kebijakan Pidana. Bandung: PT. Alumni.

Hadisuprapto, P. (2008) . Delinkuensi Anak.

Pemahamanan dan Penanggulangan. Jakarta: Bayumedia.

Kartono, K. (2017). Pathologi Sosial 2 Kenakalan

Remaja. Jakarta ; Raja Grafindo.

Lickona, T. (2013). Mendidik Untuk

Membentuk Karakter. Jakarta: Remaja

Rosdakarya.

Marzuqi, Peter M. (2005). Penelitian Hukum. Jakarta:

Kencana Prenada Media

Santoso, Topo., \& Zulfa, Eva Achjani. (2014).

KRIMINOLOGI. Jakarta: Raja Grafindo

Persada.

Soetedjo, Wigati \& Melani. (2013). Hukum Pidana

Anak. Bandung: Refika Aditama.

\section{JURNAL}

MacKenzie, Doris Layton., Brame, Robert., McDowall, David., \& Souryal, Claire. (1995). Boot camp prisons and recidivism in eight states. Criminology, Volume 33, Issue 3, p.327.

Kilgore, Deborah., \& Meade, Susan. (2004). Look What Boot Camp's Done for Me : Teaching and Learning at Lakeview Academy. J ournal of Correctional Education, Volume 55 Issue 2, pp.170-185.

Meade, Benjamin., \& Steiner, Benjamin. (2010). The Total Effects Of Boot Camps That House Juveniles: A Systematic Review of The Evidence. University Of South Carolina, United States Volume 38 Issue 5, p.5.

Gültekin, Kübra., Gültekin, Sebahattin. (2012). Is Juvenile Boot Camp Policy Effective? International Journal of Human Sciences, Volume: 9 Issue: 1, pp.7-10.

Sofa. M. (2013) Antisipasi Degradasi Moral Di Era Global. J urnal UIN Walisongo Vol. 7, (No.2), p.4.

Cahyaningtyas, I.(2015). Pembinaan Anak Pidana Di Lembaga Pembinaan Khusus Anak Dalam Perspektif Restorative Justice. Notarius, Vol.08, (No.2), pp.5-6.

Analiansyah., \& Rahmatillah, Syarifah. (2015). Perlindungan Terhadap Anak Yang Berhadapan Dengan Hukum (Studi Terhadap Undang-Undang Peradilan Anak Indonesia 
Dan Peradilan Adat Aceh). Ar-Raniry, Vol.1, (No.1), p.10.

Bottcher,Jean., \& Ezell, Michael E. (2015) Examining The Effectiveness of Boot Camps: A

Randomized Experiment With A Long-Term Follow Up. J ournal Of Research In Crime And Delinquency, Vol. 42, (No. 3), pp.3-6.

Ningrum, D. (2015). Kemerosotan Moral Di Kalangan

Remaja: Sebuah penelitian Mengenai

Parenting Styles dan Pengajaran Adab.

UNISIA, Vol. XXXVII No. 82, pp.24

Jahroh, Windi S., \& Sutarna, Nana. (2016).

Pendidikan Karakter Sebagai Upaya

Mengatasi Degradasi Moral. Prosiding

Seminar Nasional Inovasi Pendidikan, pp.5-6.

Pambudi, Agung., Sularto, RB., \& Wicaksono, Budi. (2016). Pengaruh Sistem Pembinaan Di Lembaga Pemasyarakatan Sebagai Bentuk Pertanggungjawaban Pidana Dengan Peningkatan Jumlah Narapidana Residivis (Studi Lembaga Pemasyarakatan Kelas I A Semarang). Diponegoro Law J urnal. Vol. 5, ( No 3), pp. 7-9.

Cahyo, Edo D. (2017). Pendidikan Karakter Guna Menanggulangi Dekadensi Moral Yang Terjadi Pada Siswa Sekolah Dasar. EduHumaniora: J urnal Pendidikan Dasar Vol. 9, (No.1), p 4. 